\title{
THE IMPACT OF MARKETING MIX ON THE PURCHASE DECISION WHEN BORROWING CONSUMER LOANS
}

\author{
Handry Sudiartha Athar \\ Pascasarjana, Universitas Mataram, Mataram, Indonesia \\ andre_sudiarta@unram.ac.id
}

\begin{abstract}
The purpose of this study was to determine the importance of the influence of the marketing mix, consisting of products, prices, places, promotions, physical evidence, people and processes on the customer's decision to borrow consumer credit, and to find out which of the seven marketing mix variables had the most impact dominant in the customer's decision to borrow consumer credit from PT. Bank NTB Syariah. This study is a descriptive study with both a population and a sample of 50 people obtained by non-probability techniques that is, using targeted sampling. Data collection techniques used were interviews, observation and documentation. This type of research data is quantitative data and qualitative data. Data sources used are primary data and secondary data. Data analysis was performed by multiple regression analysis with the $\mathrm{F}$ test to test the significance of the relationship of the seven independent variables along with the dependent variable. The results showed that 1) the marketing mix of services consisting of products, prices, promotions, places, people, processes and physical evidence had a significant impact on customer loan decision making; 2) Process variables have the most dominant influence on the customer's decision to borrow consumer credit from PT. Bank NTB Syariah.
\end{abstract}

\section{Keywords: Marketing Mix; Customer Decision; Consumptive Credit}

\section{Introduction}

The development of today's business world has led to the emergence of new banks or service companies with a banking-like business field, making competition increasingly difficult to enter, retain and lead a market by a particular company (Aco \& Endang, 2017). It will really be in vain all efforts of the bank to find and find new methods in the production process if this is not accompanied by sufficient sales power. Given this reality, marketing is one of the most important factors for the success of achieving business goals (Jumriaty, 2019) (Atmoko, 2018).

In the services sector, a marketing strategy is also absolutely necessary to increase sales volume (Atmoko, 2018). So far, marketers have known four basic components or elements in the marketing mix, namely product, price, promotion and distribution or what is commonly referred to as 4P (product, price, place and promotion) (Goi, 2009)(Srisusilawati, 2017)(Syah, 2014) (Thabit \& Raewf, 2018). In service marketing, there are other elements that can be monitored and combined for communication with service consumers. These elements are: people (people or personal traits), the physical environment in which the service is provided or physical evidence (physical evidence) and the service process itself (process) (Lengkong et al., 2018) (Tengku \& Yanbro, 2016). Thus, the existing 4Ps have become a marketing mix of goods, it should be expanded to 7Ps if it 
is to be used in marketing services (Rafiq \& Ahmed, 1995).

The customer's decision to obtain credit from a financial institution is influenced by several factors, such as lending procedures, credit institution services, the set interest rate or collateral required to obtain the credit (Badulescu, 2010). Generally, customers prefer to obtain credit from non-bank credit institutions because the procedure is simpler and the service faster (Ozili, 2018)(Susilawati et al., 2019). While at banking institutions, customers often face complicated procedures or procedures that have long been considered difficult for customers.

PT. BANK-LKP is one of the companies engaged in services, which is collecting public funds through savings and channeling credit loans to the public. According to Law No 10 of 1998 on banking, the definition of Rural Bank (BANK) is "a bank that conducts business activities in a conventional or business manner, whereby its activities do not provide services in the payment system".

Consumer behavior analysis is the first step in planning a marketing strategy to identify the underlying motives of customers for lending to PT. Bank NTB Syariah by knowing which factors influence the consumer's decision. So as a demand for PT. Bank NTB Syariah to identify consumer needs to formulate an appropriate marketing mix strategy to strengthen its market presence.

For this reason, from year to year PT. Bank NTB Syariah always makes improvements in the field of entrepreneurship, both in the field of human resources and the company itself. A form of
PT effort. Bank NTB Syariah increases its competitiveness with other financial institutions, namely by lowering the interest rates for consumer loans from 30\% per year to $24 \%$ per year. In addition, by adding additional funds for consumer loans with a capital increase by the owner by $50 \%$ of the initially available funds. Based on the opinions and expectations of customers towards the company, the company can continue to strive to improve the offered service product to meet the needs and wishes of customers. Because customer satisfaction is one of the keys to increasing quality and sales volume, which gives the Bank maximum benefit.

The products sold by PT. Bank NTB Syariah is savings, term deposits, business loans or working capital loans and consumer loans. The target of PT. Bank NTB Syariah is a weak middle-class community, including farmers, traders, farmers, civil servants and private workers, and small businesses near their work area that have not yet been reached for commercial banks.

The main task of PT. Bank NTB Syariah helps to encourage economic growth and regional development by providing a source of finance to productive companies of a weak economic group to improve the living standards of people, especially rural communities. To perform these basic tasks, PT. Bank NTB Syariah West Lombok has a function to: 1) stimulate the level of regional economic growth to improve people's lives; 2) equal sharing of business opportunities for the economically weak, medium and small traders; and 3) one source of regional original income.

Types of credit facilities provided by PT. Bank NTB Syariah West Lombok are: 
1) Business loans or working capital loans, namely loans provided by banks for various business sectors, including agricultural loans, animal loans, industrial loans, education loans, housing loans and other business sectors; 2) Consumer credit, namely credit used for personal consumption. In this case, there is no increase in goods and services used by a person or business unit.

Consumer loans are loans granted to clients who work as civil servants and to the general public with a minimum ceiling of Rp. 500,000; and a maximum of $\mathrm{Rp}$. $20,000,000$; with an interest of $24 \%$ per year. This appropriation is intended to cover the needs and requirements of clients working as civil servants and communities working as entrepreneurs as they need soft loans to meet consumer needs with a maximum lending period of 4 years.

Compared to working capital/business loans, consumer loans have many advantages, including a lower interest rate of $24 \%$ per annum and business loans of $30 \%$ per annum. In addition, the maximum lending period is 4 years for consumer loans, while for business loans the maximum lending period is only 3 years. However, according to information from the bank, the number of customers and sales for business loans is much higher compared to consumer loans, it is an attraction to investigate further the cause.

Given the intense competition between banks, both private and large capital state banks, in the marketing of their products, PT. Bank NTB Syariah cannot ignore the factors influencing customers when making credit decisions, especially consumer loans, such as the marketing mix that cannot be separated from PT. Bank NTB Syariah management's attention because it can be used to define marketing strategies.

As a general description in this study, the number of customers and the development of consumer credit sales revenue presented at PT. Bank NTB Syariah. In fiscal year 2015, the number of customers increased by $15.24 \%$ compared to 2014, while sales on credit sales decreased $(-45,23 \%)$ from 2014. In fiscal 2016, the number of customers increased by $200 \%$ or a difference of $184,76 \%$ from 2015, and sales increased by $163,50 \%$, which is a quite drastic increase from 2015. According to the bank's statement, this increase was due to a fall in interest rates from $30 \%$ to $24 \%$ per year.

In fiscal 2017, the number of customers increased by $108,26 \%$, followed by an increase in sales by $80.96 \%$, a smaller increase compared to the increase in 2016. In 2018, the number of customers decreased by $(-8.07 \%)$, while the number of loans actually increased by $88,97 \%$. According to information obtained from PT. Bank NTB Syariah West Lombok, the decrease in the number of customers is due to the cancellation of bad debts and this is quite detrimental for the PT. Bank NTB Syariah. While the drastic increase in consumer credit sales in 2016 was the result of a capital increase by the owner and an increase in market share by visiting agencies or offices directly on the island of Lombok.

Based on this explanation, this research was conducted with the aim of knowing the significance of the influence of the marketing mix consisting of products, prices, places, promotions, physical 
evidence, people, and processes on customer decisions in borrowing consumer loans at PT. Bank NTB Syariah West Lombok, and to find out which variable of the seven marketing mix variables has the most dominant influence on customer decisions in borrowing consumer credit at PT. Bank Syariah NTB, West Lombok.

\section{Metode}

This type of research is descriptive. This research was conducted at PT. Bank NTB Syariah located at Jl. KH. Ahnad Dahlan No. 100, Perampuan, Labuapi District, West Lombok Regency. The study population consists of clients who take out consumer credit with PT. Bank NTB Syariah, then the data collection method uses the sampling method. The sampling measurement method is a method of collecting data from part of the population studied and used to describe the characteristics and characteristics of the population. No fewer than 50 respondents were taken in this study. Determination of respondents is done by non-probability techniques, namely using targeted sampling, i.e. the technique of determining the sample with certain considerations.

Research data obtained directly from employees of PT. Bank NTB Syariah and respondents based on a list of available questions. Analysis of the data of this study using Multiple Regression Analysis. This analysis is used to see the magnitude of the influence of the independent variables, namely product, price, place, promotion, process, people and physical evidence on the dependent variable, namely the decision of the customer to borrow consumptive credit with the equation:
$\mathrm{Y}=\mathrm{a}+\mathrm{b} 1 \mathrm{X} 1+\mathrm{b} 2 \mathrm{X} 2+\mathrm{b} 3 \mathrm{X} 3+\mathrm{b} 4 \mathrm{X} 4+$ $\mathrm{b} 5 \mathrm{X} 5+\mathrm{b} 6 \mathrm{X} 7+\mathrm{b} 7 \mathrm{X} 7$

In this case, the F test is used as a simultaneous test, namely to test the significance of the relationship between the seven independent variables together on the dependent variable. The research design is as shown in Figure 1.

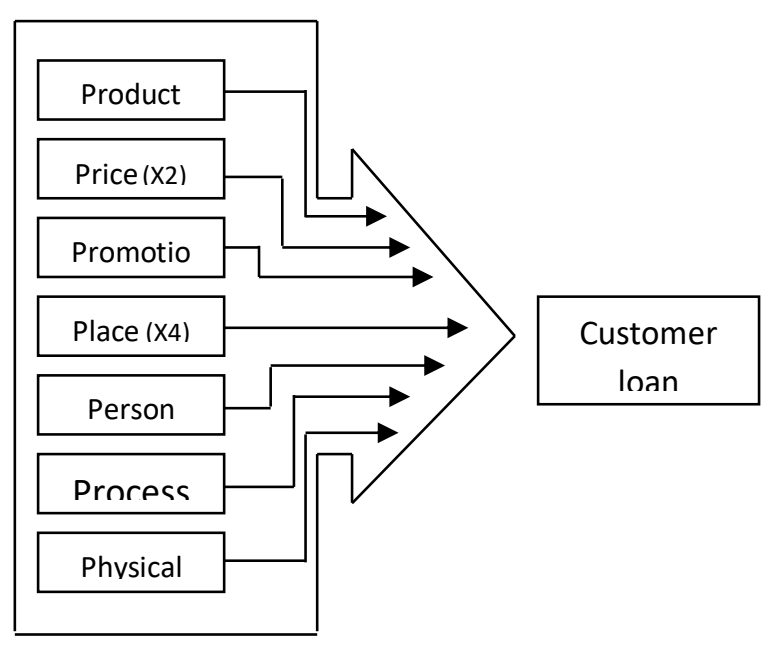

Figure 1: Research Design

II. Discussion

The results of the analysis are shown in Table 1.

Table 1. Results of Multiple Regression Analysis

\begin{tabular}{|l|l|l|l|}
\hline $\begin{array}{l}\mathrm{N} \\
\mathrm{o}\end{array}$ & Variable & $\begin{array}{l}\text { Coefficie } \\
\mathrm{nt}\end{array}$ & $\begin{array}{l}\text { Coefficie } \\
\text { nt Value }\end{array}$ \\
\hline 1 & $\begin{array}{l}\text { Product } \\
(\mathrm{X} 1)\end{array}$ & $b 1$ & $+0,727$ \\
\hline 2 & Price (X2) & $b 2$ & $+1,168$ \\
\hline 3 & $\begin{array}{l}\text { Promotion } \\
(\mathrm{X} 3)\end{array}$ & $b 3$ & $+0,503$ \\
\hline 4 & $\begin{array}{l}\text { Location(X } \\
4)\end{array}$ & $b 4$ & $-0,116$ \\
\hline 5 & Person (X5) & $b 5$ & $-0,213$ \\
\hline 6 & $\begin{array}{l}\text { Process } \\
(\mathrm{X} 6)\end{array}$ & $b 6$ & $+1,470$ \\
\hline 7 & $\begin{array}{l}\text { Physical } \\
(\mathrm{X} 7)\end{array}$ & $b 7$ & $-0,249$ \\
\hline koefisien konstanta $a=4,206$ \\
\hline
\end{tabular}


1. Effect of product variable (X1) on customer decisions (Y)

Based on the results of calculations in

Table 1, obtained a regression coefficient (b1) of +0.727 , this means that product variables positively influence customers when making decisions to borrow consumer credit from PT. Bank NTB Syariah. Improving the product variable, both by variations in product types and by improving the quality of its credit products, will have a positive impact on the customer's decision to lend consumer credit to the Bank. The results of this research are consistent with the results of research conducted by Huda et al., (2019) that Quality of service, credit procedures and interest rates significantly impact customer lending decisions at $82.1 \%$, while the remaining $17.9 \%$ is affected by other factors, namely product, promotion, location, customer relationship marketing (CRM) and others.

\section{Effect of price variable (X2,) on customer decisions (Y)}

Based on the calculation results in Table 1, a regression coefficient (b2) of $+1,168$ was obtained, which means that the price variable has a positive impact on the customer when making the decision to borrow consumer credit from PT. Bank NTB Syariah. If the price variable is wiser, for example by lowering the interest rate of credit loans to customers, this may have a positive impact on the customer's decision to take the decision to borrow consumer credit. The rise in interest rates on loans and the high administrative costs can negatively influence the customer's decision to borrow (Huda et al., 2019). Prices affect customers to borrow from the bank (Suprapto, 2011).
3. The effect of promotion variables (X3,) on customer decisions (Y)

Based on the results of calculations in Table 1 obtained a regression coefficient (b3) of +0.503 , this means that the promotion variable positively influences the customer when making the decision to borrow consumer credit from PT. Bank NTB Syariah. If the promotion is more intensive and practical, it will be delivered directly to the customer or through promotional media, it will increase the trust of new customers and enable the Bank to get new customers.

4. Effect of place variable (X4) on customer decisions (Y)

Based on the results of calculations in Table 1 obtained a regression coefficient (b4) of -0.116 , this means that the place variable has a negative impact on the customer when making the decision to borrow consumer credit from PT. Bank NTB Syariah. The existence of a Bank location does not significantly affect a customer's decision to lend to the Bank.

5. The effect of variable people (X5) on customer decisions $(\mathrm{Y})$

Based on the results of calculations in Table 1 obtained a regression coefficient (b5) of -0.213 , this means that the variable person negatively affects the customer when making the decision to borrow consumer credit from PT. Bank NTB Syariah. When employees increase the friendliness, a tidier and more pleasing appearance regarding the provision of services to customers, this will positively influence the decisions of customers.

6. Effect of process variables (X6) on customer decisions (Y)

Based on the results of calculations in Table 1 obtained a regression coefficient 
(b6) of +1.470 , this means that the process variable positively influences the customer when making the decision to borrow consumer credit from PT. Bank NTB Syariah. Running the process variable with an easy and straightforward procedure and with a short and clear time will positively influence the customer's decision.

7. Effect of physical evidence variable (X7) on customer decisions (Y)

Based on the results of calculations in Table 1, obtained a regression coefficient (b7) of -0.249 , this means that the physical evidence variable affects customers negatively when making decisions to lend consumer credit to PT. Bank NTB Syariah. Providing sufficient and sufficient physical evidence in accordance with customer expectations to support the smooth delivery of services to customers will positively influence the customer's decisions. The constant coefficient in Table 1 is $\mathrm{a}=4.206$, meaning that if the value of the seven marketing mix variables is zero, $\mathrm{Y}=\mathrm{a}=$ 4.206 (constant), meaning any change in the dependent variable can be explained by changes in any unit value of the independent variable, ie of 4,206 units.

A coefficient of determination analysis is performed to determine the percentage of marketing mix variables studied relative to the customer's decision variables. Valuation coefficient values are obtained by squaring the correlation coefficient values. The correlation coefficient is used to explain the strength of the relationship between the two variables, namely the independent variable and the dependent variable. The results of the analysis are shown in Table 2.
Table 2: Results of the Determination Coefficient Analysis

\begin{tabular}{|l|l|l|l|l|}
\hline $\begin{array}{l}\text { Mod } \\
\text { el }\end{array}$ & R & $\begin{array}{l}\text { R } \\
\text { Squar } \\
\text { e }\end{array}$ & $\begin{array}{l}\text { Adjuste } \\
\text { d R } \\
\text { Square }\end{array}$ & $\begin{array}{l}\text { Std. } \\
\text { Error } \\
\text { the } \\
\text { Estimat } \\
\text { e }\end{array}$ \\
\hline 1 & $\begin{array}{l}0,67 \\
2\end{array}$ & 0,645 & 0,672 & 0,7000 \\
\hline
\end{tabular}

From the results of the analysis in Table 2, the correlation coefficient $(\mathrm{R})$ of 0.672 was obtained. This value means that the relationship between the independent variable (marketing mix variable) and the dependent variable (the decision to borrow) is quite large and good because the value is greater than 0.5 or nearly 1.00 , which is a very good or perfect correlation value. This means that the relationship between the two variables is quite strong. Value R2 $=0.645$, meaning that $64.5 \%$ of the variations in funding decisions can be explained by variations in the marketing mix. while the remaining $35.5 \%$ is contributed by other unobserved variables.

To prove whether there is an influence or absence of the effect of variable $\mathrm{X}$ on $\mathrm{Y}$ is significant, testing will be done with the significance $\mathrm{F}$ test equipment. This test is performed to prove the effect of all marketing mix variables together (at the same time) on customer decisions. The results of the analysis are shown in Table 3 
Handry Sudiartha Athar, The Impact Of Marketing Mix On The Purchase Decision When ..

Table 3. Results of Significance analysis (ANOVA)

\begin{tabular}{|l|l|l|l|l|l|}
\hline Model & $\begin{array}{l}\text { Sum } \\
\text { of } \\
\text { Squar } \\
\text { es }\end{array}$ & $\begin{array}{l}\text { d } \\
\text { f }\end{array}$ & $\begin{array}{l}\text { Mea } \\
\text { nqua } \\
\text { Squ } \\
\text { re }\end{array}$ & F & Sig \\
\hline $\begin{array}{l}\text { Regress } \\
\text { ion }\end{array}$ & 3,420 & 7 & $\begin{array}{l}0,20 \\
3\end{array}$ & $\begin{array}{l}10,9 \\
00\end{array}$ & $\begin{array}{l}0,0 \\
8\end{array}$ \\
\hline $\begin{array}{l}\text { Residua } \\
1\end{array}$ & $\begin{array}{l}32,58 \\
0\end{array}$ & $\begin{array}{l}4 \\
2\end{array}$ & $\begin{array}{l}0,49 \\
0\end{array}$ & & \\
\hline Total & $\begin{array}{l}35,00 \\
0\end{array}$ & $\begin{array}{l}4 \\
9\end{array}$ & & & \\
\hline
\end{tabular}

Based on the calculation results in Table 3, the price of $F_{\text {count }}=10.90$ is higher than $\mathrm{F}_{\text {table }}=2.24\left(\mathrm{~F}_{\text {count }}=10.90>\mathrm{F}_{\text {table }}=\right.$ 2.24). The conclusion is that the variable marketing mix has a significant effect on the customer's decision to borrow consumer credit from PT. Bank NTB Syariah.

Then a t-test is performed to find out the significant level between the partially studied variables. This is to find out how much influence each service marketing mix variable has and to see which service marketing mix variable has the most dominant impact on customer lending decisions, where the table is 2.00 with a confidence level of $0.5 / 2=0.025$.

From the results of data analysis, t-test partially obtained the $t$ count value of each marketing mix variable, namely: product $(2,009)$, price $(2,350)$, promotion $(2,231)$, location (0.975), person (0.884), process $(2,562)$, and physical evidence $(0.963)$. The results of these calculations show that the marketing mix variable consisting of place (X4), person (X5) and physical evidence (X7) has no significant effect on the customer's decision to borrow as each $t_{\text {count }}$ value is less than the table value $(<2.00)$. This is consistent with the results of research conducted by (Putra \& Mulazid, 2018) that location does not significantly influence customers' decision to save, as well as borrow money.

Process variable (X6) has the most dominant significant impact on the customer's decision to borrow consumer credit from PT. Bank NTB Syariah. This can be seen in the $t_{\text {count }}>t_{\text {table }}$ which is $2.562>2.00$ with a significance level of 0.011 and a bet value of 1.177 . It then turns out that the variable of the marketing mix process has the most dominant influence on the customer's decision to borrow consumer credit from PT. Bank NTB Syariah.

Of all the marketing mix variables that influence customers to decide to include consumer credit, it is the process variable that has the most influence, so PT Bank NTB Syariah really needs to consider the different elements that make up the process variable with credit procedures, so have sufficiently strong influence on customer decisions, by seeking different facilities in lending procedures by further shortening the credit disbursement process and simplifying the terms of lending as customers prefer credit institutions with credit procedures and the terms and conditions of the loan are simpler and not difficult.

The price variable also greatly influences the customer's decision to take credit, so in its business activities PT. Bank NTB Syariah must always pay attention to interest rates, administrative costs and the number of credit installments paid by customers who are deemed not burdensome to customers and are able to compete with other financial institutions, especially in terms of loan interest rates. 
The Bank must pay more attention to various matters related to the place (the location of the Bank itself), people (service providers), and physical evidence (facilities that support the provision of services to customers) in order to increase customer interest, especially in making consumer loans.

Based on the results of this study, the theoretical implication is that product variables influence customers' decisions to borrow credit. If the product variable is increased by variations in the type of product or by improving the quality of the credit product, this has a positive influence on the customer's decision to borrow consumer credit from the bank. Increasing the product variable is therefore beneficial for the Bank to allow as many consumers to borrow credit as possible (Ayu et al., 2014).

Among the variables of the marketing mix, such as product, price, promotion, place, person, process, and physical proof, only product, price, promotion, and process positively affect a customer's loan decision. The results of this study provide benefits for PT. Bank Syariah NTB that in order to increase the number of customers borrowing credit, what should be considered is how to increase the marketing mix variables such as products, prices, promotions and processes. Promotion has a major influence on funding decisions (Lestari \& Magnadi, 2017). Sustomer satisfaction should be regarded as one of the main objectives of a company. Meeting this condition would provide a basis for customer loyalty which would benefit the company in the long run. With respect to pricing decisions, the customers do not solely want cheaper prices, what they want is value of the products or services equal to their expectations (Ahmed, 2015).
Theoretically, the scientific results of this research can be used as an application of economics in general and marketing management in particular. Practically, this research can contribute to the management of PT. Bank Syariah NTB as the basis for policy making, especially with regard to increasing customer interest in consumer loan lending.

\section{Conclusion}

Based on the results of the investigation, it was concluded that: 1) the marketing mix of services consisting of products, prices, promotions, places, people, processes and physical evidence had a significant impact on customer lending decisions; 2) Process variables have the most dominant influence on the customer's decision to borrow consumer credit from PT. Bank NTB Syariah. It is hoped that further research will be done in the future on the analysis of the marketing mix by using more locations and research samples so that the result can further improve the results of this research.

\section{Suggestion}

This research was only conducted at PT. Bank NTB Syariah in West Lombok Regency. Researchers suggest to do further using the same variables but a larger sample size. So that subsequent studies obtain more comprehensive research results and sharper conclusions so that companies can pay attention to important factors in increasing the amount of public loans. 
Handry Sudiartha Athar, The Impact Of Marketing Mix On The Purchase Decision When ..

\section{References}

Aco, A., \& Endang, A. H. (2017). Analisis Bisnis E-Commerce pada Mahasiswa Universitas Islam Negeri Alauddin Makassar. Jurnal Insypro, 2, 1-13.

Ahmed, S. (2015). the Effects of Marketing Mix on Consumer Satisfaction: a Literature Review From Islamic Perspectives. Turkish Journal of Islamic Economics, 2(1), 17-17. https://doi.org/10.15238/tujise.2015.2. $1.17-30$

Atmoko, T. P. H. (2018). Strategi

Pemasaran Untuk Meningkatkan Volume Penjualan Di Cavinton Hotel Yogyakarta. Journal of Indonesian Tourism, Hospitality and Recreation, 1(2), 83-96.

https://doi.org/10.17509/jithor.v1i2.13 769

Ayu, G., Suarni, P., Trupalupi, L. E., \& Haris, I. A. (2014). Analisis Faktor Yang Mempengaruhi Keputusan Nasabah Dalam Pengambilan Kredit Pada Lpd ( Lembaga Perkreditan Desa ) Desa Pakraman Manggissari. Jurnal Manajemen Pemasaran, 4(1).

Badulescu, D. (2010). SMEs Financing: the Extent of Need and the Responses of Different Credit Structures.

Theoretical and Applied Economics, 07(548)(07(548)), 25-36.

Goi, C. L. (2009). A Review of Marketing Mix: 4Ps or More? International Journal of Marketing Studies, 1(1), 215.

https://doi.org/10.5539/ijms.v1n1p2

Huda, B., Sukidin, S., \& Wahyuni, S.
(2019). Pengaruh Kualitas Pelayanan, Prosedur Kredit, Dan Tingkat Suku Bunga Terhadap Keputusan Nasabah Dalam Mengambil Kredit Pada Pt. Bank Perkreditan Rakyat Sukowono Arthajaya Jember. JURNAL PENDIDIKAN EKONOMI: Jurnal Ilmiah Ilmu Pendidikan, Ilmu Ekonomi Dan Ilmu Sosial, 13(1), 87. https://doi.org/10.19184/jpe.v13i1.104 25

Jumriaty. (2019). Strategi Pemasaran untuk Meningkatkan Penjualan pada cv. Paris Banjarbaru. Jurnal Ilmiah Ekonomi Bisnis (S4), 5(November), 77-87.

Lengkong, F., Sepang, J., Tulung, J., Sam, U., \& Manado, R. (2018). Analisis Strategi Bauran Pemasaran Eceran (Retail Marketing Mix) Yang Menentukan Tingkat Kepuasan Konsumen (Studi Pada Perusahaan Matahari Dept. Store Mtc Manado). Jurnal EMBA: Jurnal Riset Ekonomi, Manajemen, Bisnis Dan Akuntansi, 5(3), 4385-4394.

https://doi.org/10.35794/emba.v5i3.18 643

Lestari, H. Y. P., \& Magnadi, R. H. (2017). Analisis Faktor-Faktor Yang Berpengaruh Terhadap Keputusan Nasabah Untuk Mengambil Pembiayaan Pada Bmt Al Halim Temanggung. Diponegoro Journal of Management, Vol. 6(No. 1), h. 1-11.

Ozili, P. K. (2018). Impact of digital finance on financial inclusion and stability. Borsa Istanbul Review, 18(4), 329-340. https://doi.org/10.1016/j.bir.2017.12.0 
03

Putra, E. R. H., \& Mulazid, A. S. (2018).

Pengaruh Lokasi, Bagi Hasil dan Promosi terhadap Proses Keputusan Nasabah Menabung di PT Panin Dubai Syariah Bank. Li Falah: Jurnal Studi Ekonomi Dan Bisnis Islam, 3(1), 4.

Rafiq, M., \& Ahmed, P. K. (1995). Using the 7Ps as a generic marketing mix: An exploratory survey of UK and European marketing academics. Marketing Intelligence \& Planning, 13(9), 4-15.

https://doi.org/10.1108/026345095100 97793

Srisusilawati, P. (2017). Kajian Komunikasi Pemasaran Terpadu Dalam Mendorong Keputusan Pembelian Jasa Perbankan. Amwaluna: Jurnal Ekonomi Dan Keuangan Syariah, 1(1), 1-18. https://doi.org/10.29313/amwaluna.v1i 1.1993

Suprapto, E. (2011). Pengaruh fasilitas kredit, suku bunga, jangka waktu dan jumlah kredit terhadap keputusan menggunakan kredit pd bpr bkk kota semarang cabang mijen. Jurnal UNPAD, l(1), 14.

Susilawati, P. S., Ibrahim, M. A., Putra, P. A. A., \& Hidayat, Y. R. (2019). The Effectivity of Education Program of the Sharia Fund. 229-231. https://doi.org/10.2991/sores18.2019 .54

Syah, M. F. J. (2014). Pengaruh Kepuasan Konsumen Sebagai Mediator Bauran Pemasaran terhadap Keputusan Pembelian (Studi Pada Rumah Makan
Pondok Padi Organik di Sragen). Journal of Economic Education, 3(2), 206-213.

Tengku, N., \& Yanbro, A. M. (2016). ancangan Strategi Pemasaran Menggunakan Metode Ahp dan Marketing Mix (Studi Kasus PT. XXX Pekanbaru). Prosiding Seminar Nasional XI "Rekayasa Teknologi Industri Dan Informasi 2016 Sekolah Tinggi Teknologi Nasional Yogyakarta, 6.

Thabit, T. H., \& Raewf, M. (2018). The Evaluation of Marketing Mix Elements: A Case Study. International Journal of Social Sciences \& Educational Studies, 4(4). https://doi.org/10.23918/ijsses.v4i4p1 00 